\title{
Pengaruh Inokulasi Azotobacter Penghasil Eksopolisakarida terhadap Berat Kering dan Kandungan Kadmium Kubis (Brassica oleracea) di Tanah yang Dikontaminasi Kadmium
}

\author{
Reginawanti Hindersah dan Dedeh H. Arief \\ Jurusan Ilmu Tanah Fakultas Pertanian Universitas Padjadjaran \\ Jalan Raya Jatinangor Km. 21 Bandung 40191 \\ Korespondensi: reginawanti@yahoo.com
}

\begin{abstract}
Effect of Exopolysachharides-producing Azotobacter on Dry weight and Cadmium Content of Cabbage (Brassica oleracea) Grown in Cd-contaminated Soil

Cadmium (Cd) could enter agricultural land from inorganic fertilizer especially phosphate fertilizers. Accumulator plant such as plants belong to Brassicacea could accumulate Cd without any toxicity symptoms. Cadmium uptake could be increased with Azotobacter inoculation since this rhizobacteria produce exopolysachharides that mobilize heavy metal. This green house experiment has been done to evaluate $\mathrm{Cd}$ content enhancement in shoot of cabbage grown in Cd-contaminated soil following Azotobacter inoculation. Experimental design was factorial randomized block design with $\mathrm{CdCl}_{2}$ application on Andisol as first factor and Azotobacter isolates as the second one. The results showed that Azotobacter sp. LKM6 increased shoot $\mathrm{Cd}$ of cabbage grown in Cd-contaminated soil. In this experiment, cabbage grown in Cd-contaminated soil did not show any toxicity symptoms.
\end{abstract}

Key words: Azotobacter, Cabbage, Cadmium.

\begin{abstract}
ABSTRAK
Di lahan pertanian, kadmium (Cd) dapat berasal dari pupuk anorganik terutama pupuk fosfat. Kadmium dapat diakumulasi dalam jumlah berlebih di tanaman akumulator seperti keluarga Brassicacea tanpa gelaja keracunan. Serapan Cd dapat meningkat jika disertai inokulasi pupuk hayati Azotobacter yang menghasilkan Eksopolisakarida. Penelitian ini bertujuan untuk mengevaluasi peningkatan kandungan $\mathrm{Cd}$ di tajuk tanaman kubis yang ditanam di tanah dikontaminasi Cd melebihi ambang batas setelah inokulasi bakteri Azotobacter. Percobaan rumah kaca dirancang dalam rancangan acak kelompok pola faktorial dengan aplikasi $\mathrm{CdCl}_{2} \mathrm{ke}$ tanah Andisols sebagai faktor pertama dan inokulasi isolat Azotobacter sebagai faktor kedua. Hasil penelitian memperlihatkan bahwa inokulasi Azotobacter isolat LKM6 meningkatkan kandungan Cd tajuk kubis yang ditanam di tanah yang dikontaminasi Cd melebihi ambang batas. Pada penelitian ini tanaman kubis yang ditanam di tanah dikontaminasi $\mathrm{CdCl}_{2}$ tidak memperlihatkan gejala keracunan.
\end{abstract}

Kata kunci: Azotobacter, Kubis, Kadmium.

\section{PENDAHULUAN}

Kadmium adalah logam berat non esensial yang perlu diperhatikan karena Cd - bersama dengan Ni dan $\mathrm{Zn}$ - adalah logam berat yang paling akhir diadsoprsi tanah dibandingkan dengan $\mathrm{Cr}, \mathrm{Pb}$ dan $\mathrm{Cu}$ (Gomes et al. 2001) sehingga Cd relatif lebih tersedia untuk tanaman. Kandungan $\mathrm{Cd}$ tanah di atas ambang batas dapat diakumulasi dalam jumlah berlebih di tanaman, terutama tanaman akumulator. Brassicacea adalah tanaman sayuran yang banyak mengakumulasi kadmium (Alloway, 1995b) padahal sayuran ini banyak dikonsumsi masyarakat. 
Di tanah pertanian tanaman sayuran, peningkatan konsentrasi $\mathrm{Cd}$ di tanah pertanian dapat disebabkan oleh pupuk terutama pupuk fosfat dan pupuk kandang (Alloway, 1995b; Chien et al. 2003). Batuan fosfat adalah batuan sedimen yang mengandung Cd dengan konsentrasi <10-980 mg $\mathrm{kg}^{-1}$ (Mengel \& Kirkby, 1987; Alloway, 1995b) sehingga kandungan Cd di dalam pupuk fosfat akan bervariasi. Roechan et al. (1995) melaporkan bahwa kandungan Cd pupuk fosfat berkisar 30-60 mg kg-1. Konsentrasi Cd di tanah yang diberi pupuk NPK dalam jangka waktu panjang dapat meningkat sampai 25,6 \% (Palaniappan et al. 2002). Aplikasi pupuk fosfat bersamaan dengan pupuk $\mathrm{KCl}$ juga dapat meningkatkan konsentrasi Cd tanaman karena terbentuk $\mathrm{CdCl}_{2}$ yang mobil di larutan tanah (Chien et al. 2003). Umumnya tanah mengandung Cd sebesar 0,1-1 mg kg-1 dan dinyatakan terkontaminasi Cd jika konsentrasinya menjadi 3-10 mg kg-1(Mengel \& Kirkby, 1987).

Penggunaan pupuk hayati juga berpotensi meningkatkan serapan Cd oleh akar tanaman melalui berbagai mekanisme. Rizobakteri dapat meningkatkan serapan Cd akar melalui peningkatan pertumbuhan perakaran baik yang disebabkan oleh produksi fitohormon maupun fiksasi nitrogen. Mekanisme lainnya adalah kompleksasi Cd oleh eksopolisakarida (EPS) yang mobil (Chen et al. 1995). Azotobacter adalah salah satu mikroba yang hidup di rizosfer tanaman dan banyak digunakan sebagai pupuk hayati. Bakteri Azotobacter penghasil EPS telah diisolasi dari rizosfer tanaman sayuran termasuk kubis merah, dari lumpur Instalasi Pengolahan Air Limbah (IPAL) dan dari tanah hutan sekunder (Hindersah et al. 2006).

Intensitas penggunaan pupuk organik dan pupuk fosfat di tanah Andisol di Lembang Bandung termasuk tinggi karena produksi tanaman sayuran selalu mensyaratkan pemberian bahan organik. Pupuk $\mathrm{P}$ sering diberikan karena mineral amorf alofan di Andisols memfiksasi $\mathrm{P}$ menjadi tidak tersedia. Sebagian kecil petani sayuran Lembang sudah mengurangi dosis pupuk $\mathrm{P}$ dan menggantikannya dengan pupuk organik cair. Umumnya pupuk organik mengandung rizobakteri Azotobacter baik yang sengaja ditambahkan maupun berasal dari bahan dasar pupuk.

Isu lingkungan dan keamanan pangan akan terus menurunkan dosis pupuk anorganik dan menggantikannya dengan pupuk organik maupun pupuk hayati. Mengingat potensi akumulasi logam berat oleh pupuk hayati Azotobacter, maka penelitian ini dilakukan untuk mengevaluasi peningkatan kandungan $\mathrm{Cd}$ di tajuk tanaman kubis yang ditanam di tanah dikontaminasi Cd melebihi ambang batas setelah inokulasi Azotobacter.

\section{BAHAN DAN METODE}

\section{Azotobacter}

Isolat Azotobacter BS3, LKM6 dan LH15 masingmasing disolasi dari lumpur IPAL PDAM (Cd 4,73 $\mathrm{mg} \mathrm{kg}^{-1}$ ), rizosfer kubis merah yang dibudidayakan di Andisol Lembang (Cd 0,48 $\mathrm{mg} \mathrm{kg}^{-1}$ ) dan tanah Andisols di hutan sekunder Lembang (Cd 0,12 mg $\mathrm{kg}^{-1}$ ). Bakteri diisolasi dengan media Ashby bebas $\mathrm{N}$ menurut Subba Rao (1982). Induksi produksi EPS ketiga bakteri dilakukan pada media Vermani dengan nitrogen (Vermani et al., 1997). Isolat BS3, LKM6 dan LH15 masing-masing memproduksi EPS sebesar 1,6 $\mathrm{g} \mathrm{L}^{-1}$, 3,57 $\mathrm{g} \mathrm{L}^{-1}$ dan 1,73 $\mathrm{g} \mathrm{L}^{-1}$ (Hindersah et al. 2006). Ketiga isolat Azotobacter adalah koleksi Laboratorium Biologi dan Bioteknologi Tanah Fakultas Pertanian Universitas Padjadjaran.

Inkokulan cair dipersiapkan dari biakan murni berumur 72 jam di media Vermani dengan nitrogen. Kepadatan sel di dalam inokulan pada saat aplikasi adalah sekitar $10^{8} \mathrm{CFU} \mathrm{mL}^{-1}$.

\section{Percobaan Pot}

Percobaan dirancang dalam Rancangan Acak Kelompok pola faktorial dengan tiga ulangan. Perlakuan pertama adalah isolat Azotobacter penghasil EPS yaitu isolat BS3, LKM6, dan LH15, sedangkan perlakuan ke dua adalah pemberian $\mathrm{CdCl}$ yaitu dengan dan tanpa $\mathrm{CdCl}_{2}$. Perlakuan kontrol tidak mendapatkan inokulan.

Lima ratus gram tanah Andisol steril (Cd $1,21 \mathrm{mg} \mathrm{kg}^{-1}$ ) ditempatkan di dalam pot plastik. Untuk tanah yang diberi $\mathrm{Cd}, 8 \mathrm{mg} \mathrm{CdCl}_{2}$ yang dilarutkan dalam $10 \mathrm{~mL}$ air diaduk merata dengan tanah dan diinkubasi selama 3 hari. Setelah inkubasi, konsentrasi Cd di tanah yang terukur dengan ekstraski asam nitrat dan asam klorida adalah 9,01 $\mathrm{mg} \mathrm{kg}^{-1}$. Tanah di dalam pot yang tidak mendapatkan $\mathrm{Cd}$ diberi akuades steril dengan volume yang sama. Bibit tanaman kubis umur 20 hari ditanam di dalam pot plastik dan diinokulasi dengan $5 \mathrm{~mL}$ inokulan cair Azotobacter dengan isolat sesuai perlakuan. Kadar air tanaman dipertahakankan pada kapasitas lapang dan tanaman dipelihara di rumah kaca dengan selama 3 minggu.

Di akhir penelitian diukur populasi Azotobacter penghasil EPS di rizosfer kubis dengan 
metode pengenceran plat (Schinner et al., 1995) pada media Vermani. Selain itu diukur pula berat kering tajuk setelah pemanasan $70^{\circ} \mathrm{C}$ sampai berat konstan serta kandungan Cd tajuk dengan AAS setelah destruksi dengan asam (Sulaeman et al. 2005). Seluruh data dianalisis dengan analisis ragam (Uji F $5 \%$ dan dilanjutkan dengan Uji Jarak Berganda Duncan pada taraf $5 \%$.

\section{HASIL DAN PEMBAHASAN}

\section{Populasi Azotobacter}

Pada penelitian ini dilakukan sterilisasi tanah sebelum penanaman kubis sehingga Azotobacter yang terukur di akhir penelitian sebagian besar berasal dari inokulan. Di akhir penelitian, kisaran populasi Azotobacter di setiap perlakuan adalah relatif sama yaitu sekitar $10^{4} \mathrm{CFU} \mathrm{g}^{-1}$ (Tabel 1). Data ini memperlihatkan bahwa Azotobacter tetap hidup di tanah yang dikontaminasi $\mathrm{CdCl}_{2}$. Peningkatan populasi yang nyata hanya terdapat di tanah tanpa $\mathrm{CdCl}_{2}$ yang diberi isolat LKM6. Namun populasi Azotobacter LKM 6 menurun nyata pada tanah dengan $\mathrm{CdCl}_{2}$ dibandingkan tanah tanpa $\mathrm{CdCl}_{2}$. Data ini menunjukkan bahwa di dalam tanah terdapat kemungkinan penurunan populasi Azotobacter jika tanah terpapar kontaminan Cd.

Tabel 1. Interaksi antara aplikasi $\mathrm{CdCl}_{2}$ dan isolat Azotobacter terhadap populasi Azotobacter di rizosfer kubis

\begin{tabular}{|c|c|c|}
\hline \multirow{2}{*}{$\begin{array}{c}\text { Isolat } \\
\text { Azotobacter }\end{array}$} & \multicolumn{2}{|c|}{ Aplikasi $\mathrm{CdCl}_{2}$} \\
\hline & Tanpa $\mathrm{CdCl}_{2}$ & Dengan $\mathrm{CdCl}_{2}$ \\
\hline & \multicolumn{2}{|c|}{ - } \\
\hline \multirow[t]{2}{*}{ Kontrol } & $2,2 \mathrm{a}$ & $2,1 \mathrm{a}$ \\
\hline & A & A \\
\hline \multirow[t]{2}{*}{ BS3 } & $3,2 \mathrm{a}$ & $3,5 \mathrm{a}$ \\
\hline & A & A \\
\hline \multirow[t]{2}{*}{ LKM6 } & $9,7 \mathrm{~b}$ & $5,2 \mathrm{a}$ \\
\hline & A & B \\
\hline \multirow[t]{2}{*}{ LH15 } & $5,5 \mathrm{a}$ & $4,2 \mathrm{a}$ \\
\hline & A & A \\
\hline
\end{tabular}

Keterangan: Niai rata-rata yang diikuti huruf kecil yang sama (kolom) atau oleh besar yang sama (baris) adalah tidak berbeda nyata menurut uji Jarak Berganda Ducan pada taraf $5 \%$.

Penghambatan Cd terhadap daya hidup pemfiksasi $\mathrm{N}$ nonsimbiotik maupun aktivitas nitrogenase telah diteliti. Athar \& Ahmad (2002) menyimpulkan bahwa $\mathrm{Cd}$ adalah logam berat paling toksik untuk $A$. Chroococcum, dengan efek penghambatan maksimal di tanah mencapai $84,9 \%$.
Penelitian sebelumnya memperlihatkan bahwa ketiga isolat relatif resisten terhadap $\mathrm{Cd}$ di dalam kultur cair sebesar 0,01-0,1 mM tetapi dihambat oleh $1 \mathrm{Mm} \mathrm{CdCl} 2$ (Hindersah et al. 2009). Penghambatan tersebut berlaku hanya terjadi pada isolat LKM6, isolat lainnya sesuai dengan penelitian in vitro tidak terjadi pada isolat BS3 dan LH15.

\section{Berat Kering dan Kadmium Tajuk}

Secara umum, aplikasi $\mathrm{CdCl}_{2}$ tidak mempengaruhi pertumbuhan tanaman sehingga berat kering tajuk tanaman yang ditanam di tanah tanpa Cd tidak terlalu berbeda dengan yang ditanam di tanah dikontaminasi Cd (Tabel 2). Namun, inokulasi Azotobacter isolat LH15 dengan nyata meningkatkan berat kering tajuk kubis umur 3 minggu. Aplikasi isolat ini meningkatkan berat kering tajuk sampai $30 \%$. Kadmium adalah logam berat non esensial yang dianggap toksik. Data di atas memperlihatkan bahwa keberadaan Cd berlebih di tanah tidak menyebabkan efek toksik untuk tanaman akumulator $\mathrm{Cd}$, kubis.

Tabel 2. Interaksi antara aplikasi $\mathrm{CdCl}_{2}$ dan isolat Azotobacter terhadap berat kering tajuk kubis

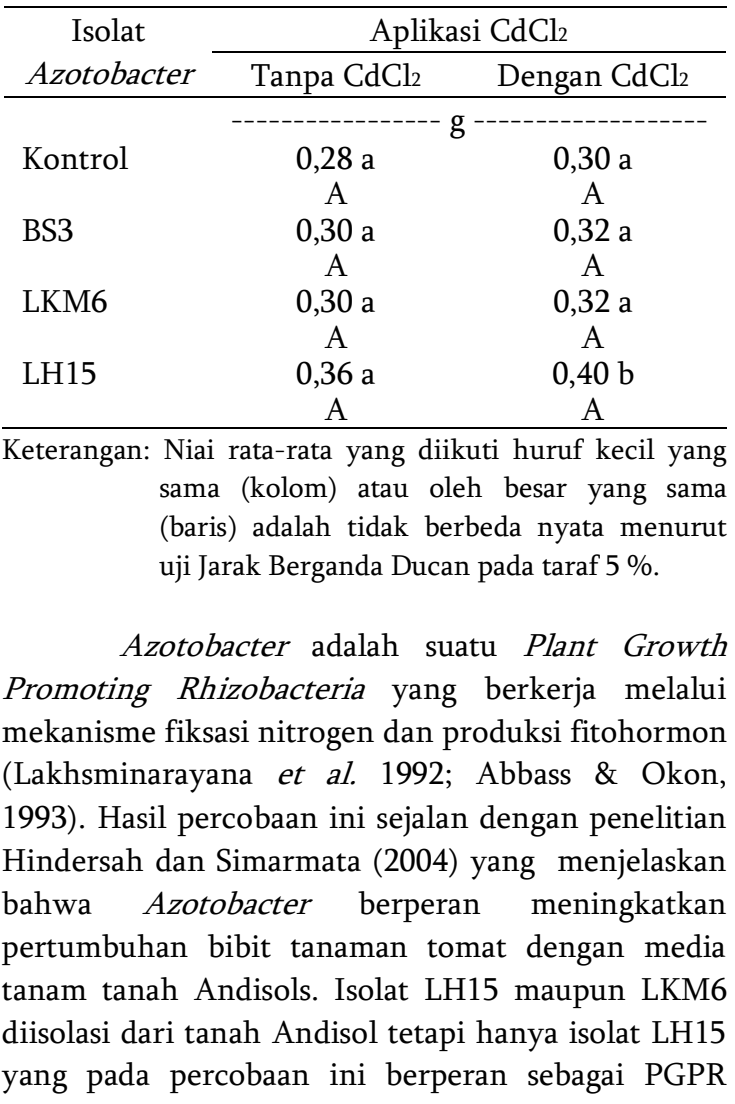


yang efektif. Diduga produksi fitohormon isolat ini relatif banyak sehingga mampu meningkatkan perakaran dan selanjutnya tajuk tanaman.

Data pada Tabel 3. membuktikan bahwa aplikasi $\mathrm{CdCl}_{2}$ meningkatkan kandungan $\mathrm{Cd}$ di tajuk selada baik yang ditanam tanpa maupun dengan aplikasi Azotobacter. Namun, hanya inokulasi isolat LKM6 yang meningkatkan kandungan Cd tajuk selada yang ditanam di tanah dikontaminasi $\mathrm{CdCl}_{2}$. Azotobacter adalah salah satu bakteri tanah yang menghasilkan EPS yang dapat mengadospri logam berat $\mathrm{Cr}$ dan Zn (Emtiazi et al. 2004). Peningkatan kandungan $\mathrm{Cd}$ di tajuk disebabkan oleh peningkatan ketersediaan Cd yang difasilitasi EPS yang mobil. Fenomena ini sejalan dengan pendapat Chen et al. (1995) bahwa bakteri penghasil EPS dapat memobilisasi logam berat (LB) melalui mekanisme pembentukan kompleks LB-EPS yang mobil.

Tabel 3. Interaksi antara aplikasi $\mathrm{CdCl}_{2}$ dan isolat Azotobacter terhadap Kandungan Cd di tajuk kubis

\begin{tabular}{lcc}
\hline \multirow{2}{*}{$\begin{array}{c}\text { Isolat } \\
\text { Azotobacter }\end{array}$} & \multicolumn{2}{c}{ Aplikasi $\mathrm{CdCl}_{2}$} \\
\cline { 2 - 3 } Konpa CdCl 2 & Dengan $\mathrm{CdCl}_{2}$ \\
\hline \multirow{2}{*}{ Kontrol } & 0,29 a & $1,8 \mathrm{a}$ \\
BS3 & $\mathrm{A}$ & $\mathrm{B}$ \\
& 0,31 a & $1,2 \mathrm{a}$ \\
LKM6 & $\mathrm{A}$ & $\mathrm{B}$ \\
& $0,28 \mathrm{a}$ & $2,8 \mathrm{~b}$ \\
LH15 & $\mathrm{A}$ & $\mathrm{B}$ \\
& 0,29 a & $1,5 \mathrm{a}$ \\
& $\mathrm{A}$ & $\mathrm{B}$ \\
\hline
\end{tabular}

Keterangan: Niai rata-rata yang diikuti huruf kecil yang sama (kolom) atau oleh besar yang sama (baris) adalah tidak berbeda nyata menurut uji Jarak Berganda Ducan pada taraf $5 \%$.

Kandungan Cd tajuk kubis (Tabel 3) yang ditanam di tanah dengan $\mathrm{CdCl}_{2}$ disertai inokulasi Azotobacter isolat LKM6 mencapai $2,8 \mathrm{mg} \mathrm{kg}^{-1}$ tetapi tanaman tidak memperlihatkan gejala keracunan. Fakta ini menunjukkan bahwa Cd dapat terakumulasi di jaringan tanaman tanpa memperlihatkan gejala keracunan seperti klorosis, tanaman layu dan kerdil (Alloway, 1995b).

Tanaman mengembangkan mekanisme proteksi terhadap keracunan $\mathrm{Cd}$ melalui sintesis peptida fitokelatin (PC). Peptida ini mengikat Cd dan menyimpannya di dalam vakuola dan plastid (Rauser, 1995; Eapen \& D’Souza, 2005) sehingga tidak memasuki sistem fisiologi tanaman. Kemampuan PC untuk mengkompartemen Cd dapat memproteksi tanaman dari pengaruh racun $\mathrm{Cd}$ (Eapen \& D’Souza, 2005). Dengan demikian, bahaya peningkatan $\mathrm{Cd}$ di tanah pertanian adalah jika $\mathrm{Cd}$ terakumulasi di tanaman akumulator seperti kubis yang dikonsumsi manusia.

\section{SIMPULAN}

Inokulasi Azotobacter isolat LKM6 meningkatkan kandungan Cd tajuk kubis yang ditanam di tanah dengan Cd melebihi ambang batas. Namun, setelah inokulasi Azotobacter tidak ada peningkatan kandungan Cd tajuk selada yang ditanam di tanah dengan konsentrasi Cd alami. Pada penelitian ini tanaman kubis tidak memperlihatkan gejala keracunan meskipun kandungan Cd di tajuk lebih dari $2 \mathrm{mg} \mathrm{kg}^{-1}$.

\section{UCAPAN TERIMAKASIH}

Terimakasih kepada Kepala Balai Pengawasan dan Sertifikasi Benih Tanaman Pangan dan Hortikultura Pemerintah Propinsi Jawa Barat untuk fasilitas rumah kaca selama penellitian.

\section{DAFTAR PUSTAKA}

Abbass, Z., Y. Okon. 1993. Plant growth promotion by Azotobacter paspali in the rhizosphere. Soil Biol. Biochem. 8: 1075-1083.

Alloway, BJ. 1995a. The Origin of heavy metals in soils. In Alloway, B.J (Ed). Heavy Metals in Soils. Blackie Academic \& Professional. Glasgow.

Alloway, BJ. 1995b. Cadmium. In Alloway, B.J (Ed). Heavy Metals in Soils. Blackie Academic \& Professional. Glasgow.

Athar, R and M Ahmad. 2002. Heavy metal toxicity on plant growth and metal uptake by wheat and on free living Azotobacter. Water, Air, and Pollution. 138: 165-180.

Chen, J-H, DR Czajka, LW Lion, ML. Shuler and WC Ghiorse. 1995. Trace metal mobilization in soil by bacterial polymers. Environ. Health Perspect 103: 53-58.

Eapen, S and SF D'Souza. 2005. Prospects of genetic engineering of plants for phytoremediation of toxic metals. Biotech. Adv. 23: 97-114.

Chien, SH, G Carmona, LL Prochnow and ER Austin. 2003. Cadmium availability from granulated and bulk-blended phosphatepotassium fertilizers. J. Environ. Qual. 32:1911-1914. 
Emtiazi, G, Z Ethemadifar and MH Habibi. 2004. Production of extracellular polymer in Azotobacter and biosorption of metal by exopolymer. Afr. J. Biotech. 3: 330-333.

Gomes, PC, MPF Fontes, AG da Silva, E de S Mendonca, and AR Netto. 2001. Selectivity sequences and competitive adsorption of heavy metals by Brazilian soil. Soil Sci. Soc. Am. J. 65:1115-1121.

Hindersah, R dan T Simarmata. 2004. Kontribusi rizobakteri Azotobacter dalam meningkatkan kesehatan tanah melalui fiksasi $\mathrm{N}_{2}$ dan produksi fitohormon di rizosfir. Jurnal Natur Indonesia 6: 127-133.

Hindersah, R, DH Arief, S Soemitro and L Gunarto. 2006. Exopolysaccharide extraction from rhizobacteria Azotobacter sp. Proc. International Seminar IMTGT. Medan, 22-23 Juni 2006. Pp 50-55.

Hindersah, R. DH Arief, S Soemitro dan L Gunarto. 2009. Pengaruh $\mathrm{CdCl}_{2}$ terhadap produksi eksopolisakarida dan daya hidup Azotobacter. Jurnal Natur Indonesia, 12: 34-37.

Lakshminarayana, K, H Narula, IS Hooda nad AS Faroda. 1992. Nitrogen economy in wheat (Triticum aestivum) through use of Azotobacter chroococcum. Indian Journal of Agric. Sci. 62: 75-76.

Mengel, K., and E.A. Kirkby. 1987. Principles of Plant Nutrition. International Potash Institute. Bern.
Palaniappan, M., K. Shanmugam, and S., Ponnusam. 2002. Soil degradation due to heavy metal accumulation under long term fertilization. Paper 333. Proceeding of $17^{\text {th }}$ World Congress of Soil Science, Bangkok, Thailand, 14-20 August 2002. http://citeseer.ist.psu.edu/656685.html [23/09/04]

Roechan, S., I. Nasution, L. Sukarno, A.K. Makarim. 1995. Masalah pencemaran kadmium pada padi sawah. Hal 33-37 dalam Kinerja Penelitian Tanaman Pangan. Pusat Penelitian dan Pengembangan Tanaman Pangan. Syam, M, A Hermanto, Mussadad dan Sunihardi (Ed). Badan Litbang Pertanian. Jakarta.

Rauser. W.A. 1995. Phytochelatin and related peptides. Structure, biosynthesis and function. Plant Physiol. 109: 1141-1149.

Schinner, F., R. Ohlinger, E. Kandeler, and R. Margesin. 1995. Methods in Soil Biology. Springer-Verlag. Berlin.

Sulaeman, Suparto, dan Eviati. 2005. Petunjuk Teknis Analisis Kimia Tanah, Tanaman, Air dan Pupuk. Laboratorium Tanah Balai Penelitian Tanah. Bogor.

Vermani, M.V., S.M. Kelkar, and M.Y. Kamat. 1997. Studies in polysaccharide production and growth of Azotobacter vinelandii MTCC 2459, a plant rhizosphere isolate. Lett. Appl. Microbiol. 24: 379-383. 